\title{
A MODERN POLLEN SPECTRUM FROM DYE 3, SOUTH GREENLAND ICE SHEET
}

\author{
By Jocelyne C. Bourgeois
}

(Geological Survey of Canada, Ottawa, Ontario K1A 0E8, Canada)

\begin{abstract}
Results of pollen analysis of a large firn sample from Dye 3, southern Greenland, are reported. The sample was divided into three sections: all dominated by pine, birch, and ragweed pollen. Pollen concentration for the entire sample is 15 pollen grains per litre and the annual pollen deposition rate has been estimated at approximately $0.73{\text { grain } \mathrm{cm}^{-2} \text { year }}^{-1} \quad\left(7300\right.$ grains m$\left.^{-2} \mathrm{a}^{-1}\right)$. Although these values are slightly lower than expected, considering the relatively southern latitude of the site, they are within the range of values obtained from other Arctic ice caps.
\end{abstract}

\section{INTRODUCTION}

A $15.5 \mathrm{~kg}$ firn sample (\#B-6-B) was collected for pollen analysis at Dye 3 (lat. $65^{\circ} 11^{\prime} \mathrm{N}$., long. $43^{\circ} 49^{\prime} \mathrm{W}$., $2475 \mathrm{~m}$ a.s.1.) in the southern section of the Greenland ice sheet. The purpose for sampling was, first, to obtain the modern pollen spectrum and concentration values for southern Greenland in order to compare with data obtained from Canadian Arctic ice caps (Lichti-Federovich, 1974; Bourgeois and others, 1985; Short and Holdsworth, 1985) and, secondly, to investigate the potential for pollen-analysis studies in Greenland ice-core projects.

The sample covers the late summer of 1982 to the late spring of 1983. At the site, the average accumulation is $54 \mathrm{~cm}$ (ice equivalent) per year with an average melt of $6 \%$ or $3.22 \mathrm{~cm}$ per year (Reeh and others, 1978).

\section{METHODS}

The firn was sampled in the summer of 1983 and was kept at the State University of New York at Buffalo until its transfer to our Ottawa laboratory in 1987. It was kept in a freezer for another year before being processed.

To eliminate the possibility of contamination, a few centimeters were cut from the surface, all around the sample. This material was transferred to a clean thick plastic bag. The remaining firn sample was cut in two, lengthwise, and also transferred into separate plastic bags. This was done to avoid losing the complete sample should some mishap occur during the laboratory procedure.

Each sub-sample was melted inside its plastic bag. A known amount of exotic Lycopodium spores (Stockmarr, 1971) was added to each sample as a control for pollen loss during laboratory procedure. The melt water was filtered through $50 \mathrm{~mm}$ diameter cellulose-acetate filters with poresize diameter of $8 \mu \mathrm{m}$. These filters collect pollen grains and other particulate matter in depth, rather than on the surface. The filters were then soaked overnight in hydrofluoric acid to dissolve most of their mineral content. This step was followed by a standard acetolysis procedure which dissolved the cellulose filter. The pollen residue was left on a $47 \mathrm{~mm}$ diameter Nuclepore filter (pore-size diameter of $8 \mu \mathrm{m})$, which is transparent, and can be analyzed under a microscope. The method has been described at greater length by Bourgeois and others (1985) and Bourgeois (1986).

\section{RESULTS AND INTERPRETATION}

The results are presented in number of pollen grains per titre and in pollen percentages (Table I) for each sub-sample and for the complete sample. The numbers have been corrected for pollen loss $(15 \%)$ during preparation of the samples. The percentages are presented, but only because it is the standard form used in pollen diagrams and therefore can be used for comparisons. Sub-sample \#1 represents approximately one-half of the sample, $\# 2$ the other half, while $\# 3$ represents the outer layer.

The three sub-samples show considerable variations. The pollen types, Pinus (pine), Betula (birch), and Ambrosia (ragweed) are, however, dominant in all three samples. While pine and birch are present in the boreal forest of northern Labrador and Ungava as well as in southern Greenland for the latter, ragweed is considered to reach its northern limit in southern Quebec. Picea (spruce) and Alnus (alder), major elements of the northern boreal forest, have a very low representation in the sample. Pollen from the "regional" tundra is also poorly represented. These results are similar to those obtained by Short and Holdsworth (1985) on the Penny Ice Cap of Baffin Island. However, spruce is better represented on the Penny Ice Cap. On other Canadian ice caps (Lichti-Federovich, 1974; Bourgeois and others, 1985), alder is usually one of the dominant pollen types.

Sub-sample \#3, the outer layer, has a significantly higher pollen concentration than the other two sub-samples. There are two possibilities for the difference. The outer layer might have been contaminated by exposure to air or material during transit, or in one of the laboratories. If exposed for a long period, we would expect to see a higher concentration of broad-leaf forest pollen types and also of ragweed pollen, as the sample was transferred to Ottawa during the height of ragweed-pollen production. There are no significant increases of those pollen types in the sub-sample.

Another possibility for the higher concentration in $\$ 3$ is that the top or bottom layer of the firn sample contained more pollen grains than the middle part. Those two layers were most likely deposited in late summer (1982) and in late spring (1983) when pollen deposition on ice caps is of ten higher than during the winter months (Bourgeois, in press). Either possibilities cannot be disproved at this point.

If we assume that the pollen concentration for the whole sample ( 15 grains $\left.1^{-1}\right)$ is representative of one annual layer at the Dye 3 station, then the pollen concentration is lower than expected considering the site location, near the Arctic Circle, and its relative proximity to pollen sources in the boreal forest. Fredskild and Wagner (1974), in their study of very small core samples ( 11 or less) from Camp Century and Dye 3, found for the A.D. 1936-38 period a higher pollen concentration at Camp Century (estimated 96 grains $1^{-1}$ ) than at Dye 3 (estimated 25 grains $\mathrm{I}^{-1}$ ). On the Penny Ice Cap of Baffin Island, Short and Holdsworth (1985) estimated pollen concentrations for shallow cores to vary from 41 to 124 grains $1^{-1}$, and at several sites in the Canadian High Arctic, Bourgeois and others (1985) found concentrations to vary between 0.5 and 20.2 grains $\mathrm{l}^{-1}$. 
TABLE I. SAMPLE B-6-B POLLEN CONCENTRATION IN GRAINS PER LITRE (PERCENTAGES IN BRACKETS)

Pollen type

Acer
Carya
Fraxinus
Juglans
Quercus
Tilia
Tsuga
Ulmus
Alnus
Betula
Picea
Pinus
Populus
Salix
Ambrosia
Artemisia
Chenopodiaceae
Cruciferae
Cyperaceae
Gramineae
Leguminosae
Liguliflorae
Oxyria
Potamogeton type
Rosaceae
Tubuliflorae
Saxifragaceae
Lycopodium
Sphagnum
Unknown
Indeterminable

Total pollen concentration

Pollen/spore sum

Litres
Sub-samples

$$
\# 2
$$

$$
\begin{gathered}
0.3(3.7) \\
-- \\
-
\end{gathered}
$$$$
0.3(3.7)
$$$$
-
$$$$
\text { - }
$$$$
-
$$$$
-
$$$$
-\quad-
$$$$
-
$$$$
-\quad-
$$$$
1.4(18.0)
$$$$
3.2(41.0)
$$$$
-\quad-
$$$$
0.2(2.6)
$$$$
0.8(10.3)
$$$$
0.2(2.6)
$$$$
\text { - }-
$$$$
-\quad-
$$$$
0.4(5.1)
$$$$
-\quad-
$$$$
0.2(2.6)
$$$$
0.2(2.6)
$$$$
-\quad-
$$$$
-\overline{-}
$$$$
-\quad-
$$$$
0.2(2.6)
$$$$
0.2(2.6)
$$

7.8

39

5.0

The higher snow-accumulation rate at Dye 3 must be taken into account when comparing pollen data with other sites either in Greenland or in the Canadian Arctic, as it creates a diluting effect. Table II shows the pollen deposition rates for Dye 3 as well as a few other Arctic ice caps (Fig. 1), for a more adequate comparison. The deposition rate is estimated by multiplying the accumulation rate by the pollen-concentration value. The pollen deposition rate of 0.73 grains $\mathrm{cm}^{-2}$ year $^{-1}$ (7300 grains $\mathrm{m}^{-2} \mathrm{a}^{-1}$ ) for Dye 3 is, as expected, slightly higher than the farther north sites but lower than the Penny Ice Cap site, situated at approximately the same latitude. This might be explained by the shorter distance from tree line at the Penny Ice Cap and also its proximity to local tundra sources. Dye 3 is located in an area of high accumulation and, as mentioned by Fredskild and Wagner (1974), this can cause the frequent "wash out" of pollen grains, by precipitation, before they can reach the site. Furthermore, the dominant winds at Dye 3 are from the south-east which make them unlikely to carry large amounts of pollen from forested areas.

The difference in deposition rate between Dye 3 and the glacier site in the Torngat Mountains of Labrador is quite large (from 13.75 to $0.73 \mathrm{grains} \mathrm{cm}^{-2}$ year ${ }^{-1}$ ) over a relatively short distance. This would support the observations made by Bourgeois and others (1985) that there is a steep gradient of deposition between the tree line and the High Arctic. Within the High Arctic, the distribution is flat or shows only small variations.

\begin{tabular}{|c|c|}
\hline $1.1(4.8)$ & $0.7(4.7)$ \\
\hline $0.3(1.2)$ & $0.1(0.9)$ \\
\hline- & $0.1(0.4)$ \\
\hline- & $0.1(0.9)$ \\
\hline $0.4(1.8)$ & $0.2(1.3)$ \\
\hline $0.1 \quad(0.6)$ & $0.1(0.4)$ \\
\hline $0.4(1.8)$ & $0.2(1.3)$ \\
\hline 0.8 & $0.4(2.6)$ \\
\hline $1.0(4.2)$ & $0.5(3.0)$ \\
\hline $4.6(19.9)$ & $2.8(18.5)$ \\
\hline $0.4(1.8)$ & $0.4(2.6)$ \\
\hline $4.8(21.1)$ & $3.5(23.3)$ \\
\hline $0.1(0.6)$ & $0.1(0.4)$ \\
\hline $0.1(0.6)$ & $0.1 \quad(0.9)$ \\
\hline $2.6(11.5)$ & $1.9(12.9)$ \\
\hline $1.1(4.8)$ & $0.5(3.5)$ \\
\hline $0.6(2.4)$ & $0.3(2.2)$ \\
\hline $0.1(0.6)$ & $0.1(0.4)$ \\
\hline $0.3(1.2)$ & $0.1(0.9)$ \\
\hline $1.4(6.0)$ & $0.8(5.2)$ \\
\hline $0.1(0.6)$ & $0.1 \quad(0.4)$ \\
\hline $0.1(0.6)$ & $0.1 \quad(0.4)$ \\
\hline $0.1(0.6)$ & $0.3(2.2)$ \\
\hline $0.1(0.6)$ & $0.1(0.9)$ \\
\hline-- & $0.1(0.4)$ \\
\hline $0.4(1.8)$ & $0.2(1.3)$ \\
\hline $0.1(0.6)$ & $0.1(0.9)$ \\
\hline $0.3(1.2)$ & $0.1 \quad(0.9)$ \\
\hline $0.1(0.6)$ & $0.1 \quad(0.4)$ \\
\hline $0.3(1.2)$ & $0.2(1.3)$ \\
\hline $0.8(3.6)$ & $0.7(4.7)$ \\
\hline
\end{tabular}

Total

$\# 3$

15.0

232

15.4

\section{CONCLUSION}

Pollen concentration at Dye 3 is low but unexceptional when seen in terms of deposition rate per year. The high accumulation and low pollen concentration indicate that a large volume (minimum of $10 \mathrm{l}$ ) is needed to obtain an adequate pollen sum. At Crête, in central Greenland, the snow-accumulation rate is lower but the pollen-deposition rate is probably also lower, which indicates that a similar volume would be required if pollen studies were to be undertaken,

In the future, shallow cores covering a few years of accumulation might be more appropriate for obtaining an average modern pollen concentration as was first done in the Canadian High Arctic (Bourgeois and others, 1985). This could be seen as a first step in determining the value of pollen analysis for Greenland ice-core projects.

\section{ACKNOWLEDGEMENTS}

I should like to thank C.U. Hammer for providing me with the firn sample for this study and C.C. Langway for arranging its transfer from Greenland as well as storing the sample in his freezer facilities at the State University of New York, in Buffalo, for 4 years. I should also like to thank R.M. Koerner, D.A. Fisher, and an anonymous reviewer for their helpful comments and revision of the 
TABLE II. POLLEN-DEPOSITION RATES AT DYE 3 AND AT SOME CANADIAN ARCTIC ICE CAPS

Location

Deposition rate Number of grains $\mathrm{cm}^{-2}$ year ${ }^{-1}$
1. Dye 3

0.73

13.75

Mountains (Labrador)

3. Penny Ice Cap (Baffin Island)

4. Bylot Ice Cap (Bylat Island)

5. Sydkap Ice Cap (Ellesmere Island)

6. Agassiz Ice Cap

(Ellesmere Island)

7. Muller Ice Cap (Axel Heiberg Island)

0.20

0.12

0.22 years

$<1$

1

$1-8$ (seasonal) 8

3

3

12

Sources: 1. This study; 2. Bourgeois and others (1985); 3. Short and Holdsworth (1985); 4-7. Bourgeois and others (1985).

manuscript. This paper is Geological Survey of Canada Contribution No. 41489.

\section{REFERENCES}

Bourgeois, J.C. 1986. A pollen record from the Agassiz Ice Cap, northern Ellesmere Island, Canada. Boreas, 15(4), 345-354.

Bourgeois, J.C. In press. Seasonal and annual variation of pollen content in the snow of a Canadian High Arctic ice cap. Boreas.

Bourgeois, J.C., R.M. Koerner, and B.T. Alt. 1985. Airborne pollen: a unique air mass tracer, its influx to the Canadian high Arctic. Ann. Glaciol., 7, 109-116.

Fredskild, B. and P. Wagner. 1974. Pollen and fragments of plant tissue in core samples from the Greenland ice cap. Boreas, 3(3), 105-108.

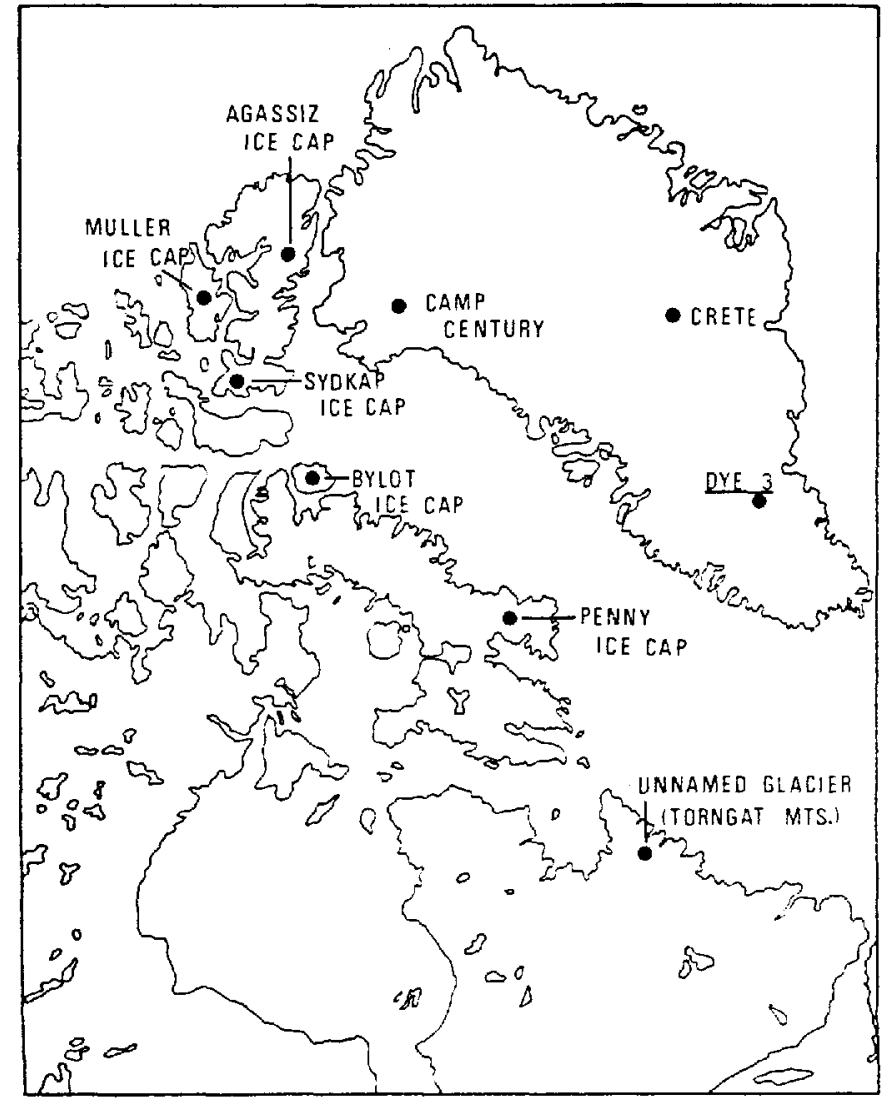

Fig. 1. Location of Dye 3 and other sites mentioned in the text. The dots refer to the sampling sites and not the surfaces of the ice caps.

Lichti-Federovich, S. 1974. Pollen analysis of surface snow from the Devon Island ice cap. Geol. Surv. Can. Pap. 74-1, Pt. A, 197-199.

Reeh, N., H.B. Clausen, W. Dansgaard, N. Gundestrup, C.U. Hammer, and S.J. Johnsen. 1978. Secular trends of accumulation rates at three Greenland stations. J. Glaciol., 20(82), 27-30.

Short, S.K. and G. Holdsworth. 1985. Pollen, oxygen isotope content and seasonality in an ice core from the Penny Ice Cap, Baffin Island. Arctic, 38(3), 214-218.

Stockmarr, J. 1971. Tablets with spores used in absolute pollen analysis. Pollen et Spores, 13, 615-621. 